\title{
TRAINING OF PROFESSIONAL FOOD TECHNOLOGIES TEACHERS AS A DIDACTIC PROBLEM
}

\author{
Mykola Korets \\ Doctor of Pedagogical Sciences, Professor, \\ National Pedagogical Dragomanov University, Ukraine \\ e-mail: m.s.korets@npu.edu.ua,orcid.org/0000-0001-5552-7481 \\ Svetlana Ishchenko \\ Postgraduate Student, National Pedagogical Dragomanov University, Ukraine \\ e-mail: s.m.ischenko@npu.edu.ua,orcid.org/0000-0001-5791-803X
}

\section{Summary}

The article considers the didactic problems that have accumulated recently at the level of training teachers in the field of food technology. They require the definition of modern approaches to effective decision-making. The didactic aspect of training teachers of the professional direction of food technologies is presented, which is: a set of interdependent forms, means and methods of training with a predetermined ultimate goal - individual readiness for future professional activity. Ways of realization of modern approaches to the decision of didactic problems in preparation of future teachers of professional training on food technologies are considered. The relationship between the main didactic categories as structural components of the whole didactic process is shown. The chain of didactic categories is analyzed in view of their didactic role in the practice of teaching technological equipment of the food industry to future teachers of vocational training. It is proved that these tasks can be successfully implemented under the condition of training competent teachers who are able to think scientifically and navigate in their practice, to make operational decisions on complex production situations. competence.

Keywords: didactics, didactic aspect, technological equipment, didactic system,

DOI: https://doi.org/10.23856/3859

\section{Introduction}

Modern society puts before higher education institutions important tasks: to train specialists who know, think, are able to independently acquire and apply in practice new knowledge and practical skills. Today in Ukraine the system of vocational education is being renewed, namely: autonomy of management the educational systems; regionalization of the content the education in combination with the implementation of the State educational standard; change of professional qualification structure of trained workers and specialists. This update is implemented by professional and pedagogical workers who need appropriate qualifications, and the current level of their qualifications does not meet the current challenges of transformation of vocational education.

The aim of research is comparison and analyze didactic problems in the training of teachers of vocational training in food technology.

Methodology of research is to use methodological approaches such as:

- acmeological approach, which provides a system of principles, techniques and methods to solve problems and problems in the study of basic didactic aspects of training teachers of vocational training in food technology; 
- activity approach, which is aimed at disclosing questions about the essence, formation and cognitive value of the categories of didactics and determining the essential characteristics of the structural and substantive elements of the process of learning the $t$ echnological equipment of the food industry.

\section{Presentation of main research material}

The rapid development of Ukraine's food industry is closely linked to the introduction of new types of enterprises, modern food production technologies, and the involvement of innovative technological equipment, which in turn requires the training of a wide range of specialists with a deep and diverse range of knowledge. Given these circumstances, it is necessary to review and gradually change the approaches to the training of teachers of vocational training in food technology, so this problem is quite relevant. The main aspects of teacher training are reflected in the research: S. Artyukha, A. Asherova, S. Batysheva, A. Belyaeva, O. Malenko, N. Nychkalo, A. Pastukhova, V. Mosolova, E. Neroba, A. Seytesheva, O. Shcherbak (conceptual principles and strategy of engineering development -pedagogical education); V. Bakatanova (selection for study at a pedagogical university); S. Bocharova, E. Zeyer (psychological training of students in engineering and pedagogical higher education); S. Guri (adaptation to study in engineering and pedagogical higher education institution); L. Kopalova (role and place of abilities in engineering and pedagogical activity), O. Dubaseniuk (technologies of professional and pedagogical training of future teachers), A. Korzhuyev, V. Popov (teaching, learning, education, training), A. Aleksyuk, A. Bondar, J. Burlaka, F. Naumenko (problems of higher school didactics), Y. Malovany, V. Onishchuk (organizational forms of education). Despite the diversity of research in domestic and foreign literature, the experience of innovative teachers, the problems of food technology in the training of teachers of vocational education in food technology in the new conditions of the educational process was given insufficient attention.

The didactic aspect is one of the most important, as technological knowledge and skills begin to be laid directly in the learning process. The level of didactic competence of the future teacher of vocational education largely depends on how the process of didactic training is organized.

Let us consider in more detail the main problems of didactics in the training of teachers of vocational training in food technology.

The term "didactics" comes from the Greek words didaktikas - the one who teaches and didasko - the one who study. This term was first introduced by the German pedagogue W. Ratke, then used by Comenius in his work "Great Didactics", the essence of which the author defined as "universal art to teach everyone." In the modern sense, didactics is a part of pedagogy that explores the problems of teaching and education. Didactics is aimed at studying and disclosing the theoretical foundations of the learning process (patterns, principles, methods, forms of learning), as well as the search for and development of new principles, strategies, techniques, technologies and learning systems (Dubasenyuk, OA, 2001).

Questions about the essence, formation and cognitive value of the categories of didactics reveal in their scientific works A. Aleksyuk and M. Yarmachenko (Aleksyuk A., 1985: 95; M. Yarmachenko, 1986: 81). V. Chaika concretizes the process of mastering education, considering it as a purposeful process and the result of students mastering the system of scientific knowledge, cognitive skills and the formation on this basis of worldview, moral qualities (Chaika V., 2002: 15).

Didactic research makes real learning processes its object, gives knowledge about regular connections between its various parties, reveals essential characteristics of structural and 
substantive elements of the learning process of technological equipment of the food industry. The scientific and theoretical function of didactics provides justification, systematization and generalization of pedagogical experience, patterns and mechanisms of personality development in the learning process.

The obtained theoretical values allow to solve many problems related to learning, namely: to bring in line with the changing goals of educational content, to determine the optimal capabilities of teaching methods and tools, to design new educational technologies and more. All this speaks of the normative-applied (constructive) function of didactics.

At the present stage of training teachers of professional training in food technology there are the following didactic tasks:

- substantiation and specification of the principles of the organization of training, ways and means of development of cognitive independence and activity of students during training of the technological equipment of branch;

- updating of educational and working programs and development of an educational methodical complex;

- research of function, structure of methods and forms of training;

- substantiation of interdisciplinary connections for actualization and systematization of basic knowledge, formation of practical knowledge, skills and abilities;

- ensuring the balance of social and personal goals in the learning process;

- development of new learning technologies.

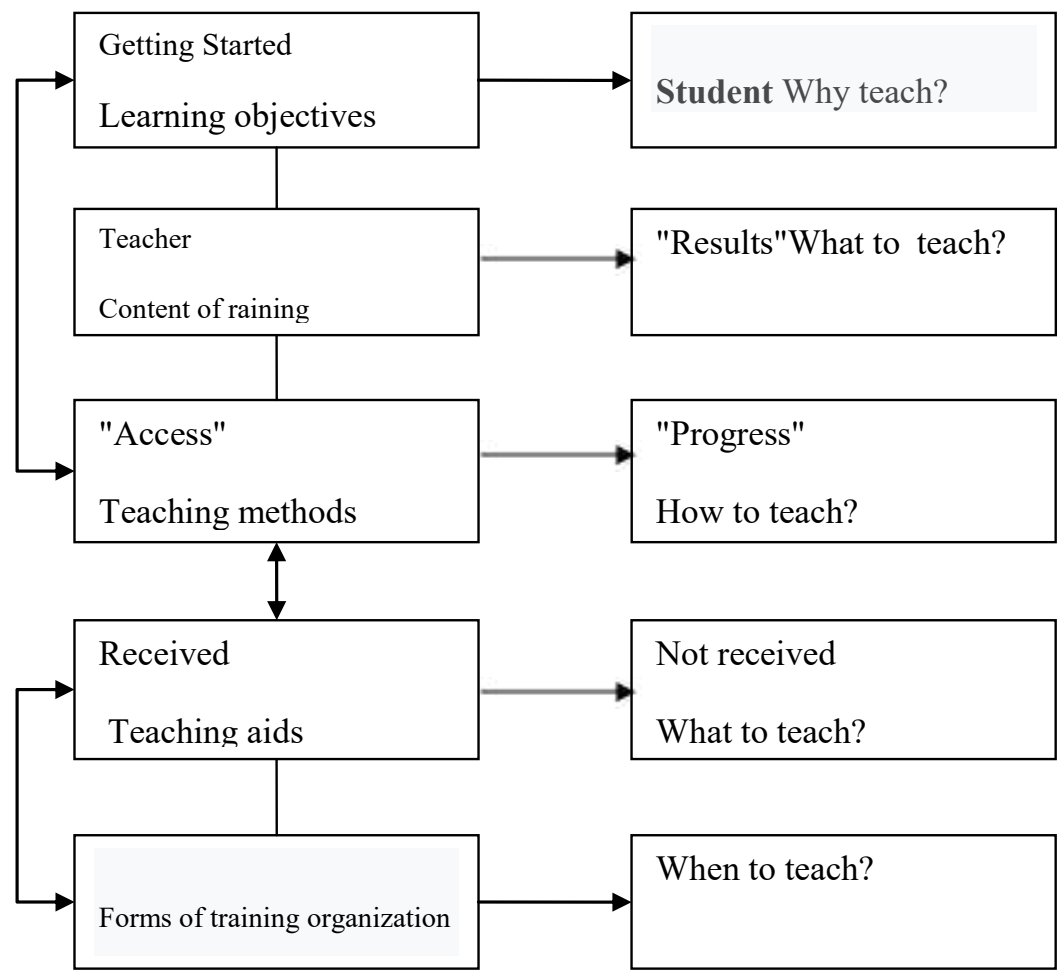

Fig. 1. Components of the didactic system 
The didactic system is a set of principles, forms, methods and teaching aids of a certain didactic concept, ie a certain understanding of the goals, essence, laws and patterns, mechanisms of learning and personal development. This is the formation of typical ways of working on the basis of assimilated information, resulting in the concept of programmed learning. If learning is interpreted as a way to develop creative abilities, then the concept of problem-based learning corresponds to this approach. The set of didactic elements is shown in Fig. 1.

The didactic system is divided into the following categories:

- teaching - orderly activity of the teacher on realization of the purpose and tasks of training, maintenance of informing, perception, awareness, mastering and practical application of knowledge;

- learning - the process of students' own activities, during which on the basis of knowledge, training and experience gained in them are formed and improved knowledge, skills, forms of activity and behavior, learning, education (Fig. 2);

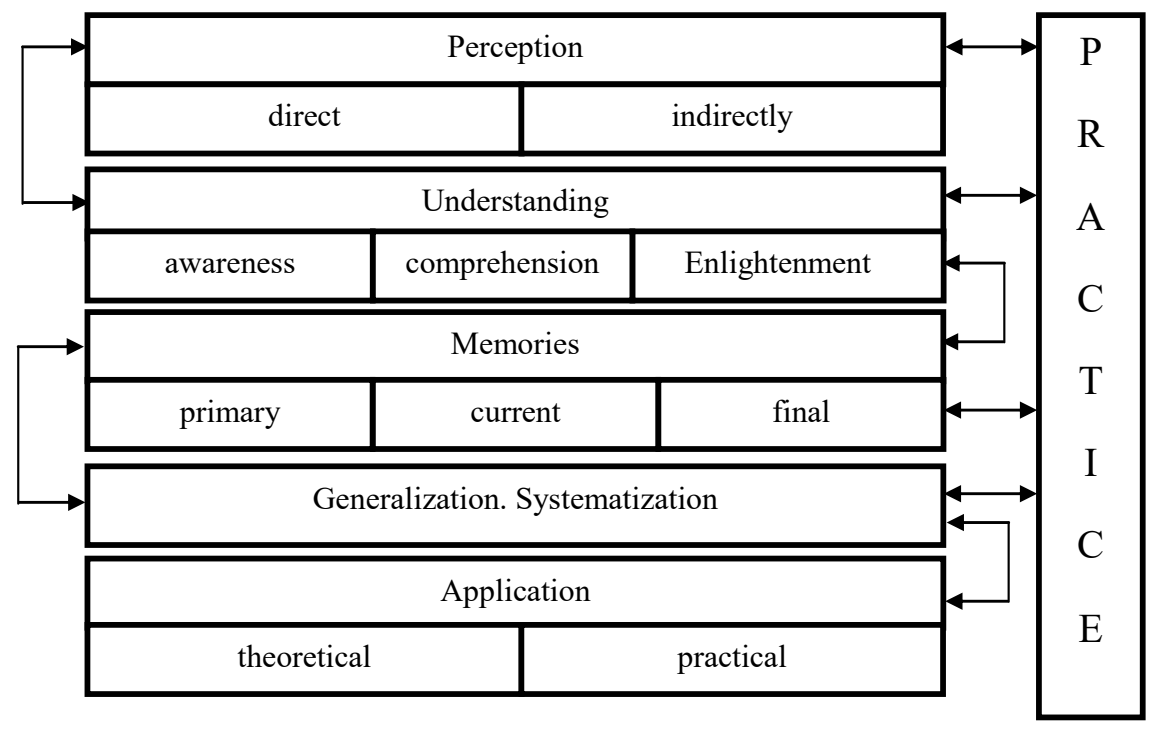

Fig. 2. The main stages of the learning process

- training - joint activities of teachers and students, orderly cooperation aimed at achieving the goal;

- knowledge - a reflection of the cognizable world in human thought; a set of ideas that reflect the theoretical mastery of a particular subject;

- skills - mastering the methods (techniques, actions) of applying the acquired knowledge in practice; directed;

- skills - skills brought to automatism, a high degree of perfection;

- goal (educational) - that to which learning aspires, the future on which its efforts are

- results (learning products) - what learning achieves, the final results of the learning process.

The process of didactic training of teachers of vocational training in food technology will be effective if it is purposeful and manageable, ie that the process of didactic training was 
creative, built on the basis of individualization. To do this, in the learning process should pay attention to the acquisition of theoretical knowledge of the professional subject area and bring them to well-formed skills. Students must clearly understand the specifics and relationship of tasks, both didactics and methods of teaching technological equipment in the food industry. The theoretical knowledge obtained in higher education institutions in this case is based on the observation of students during lectures, seminars, practical and laboratory classes. To better master the learning process, the teacher must receive information about how the student learns the material (external feedback). The means of management in our case are educational and didactic tasks performed by students independently or together with others (Kurdanova H., Sarbasheva Z., 2008: 32-33). That is, knowledge must be formed not in isolation, but in conjunction with the methods of their transfer and assimilation.

The problem of teaching in the didactic training of students requires a systematic approach. In recent years, a number of works have been published on the consideration of pedagogical systems in their general form. The pedagogical system is defined as a multifaceted education that contains many interconnected elements that form a stable unity and integrity, with integrative properties and subordinate to the goals of education, training and preparation for future professional activities.

The need for a systematic approach in the method of teaching technological equipment in the food industry is due to the fact that traditional research methods in the study of complex objects have proved noneffective. Therefore, there is a need to represent a complex object as a system, as a holistic entity, which makes it possible to explore not only the object itself, but also its connections and relationships.

When solving learning problems, we definitely touch on the content and goals of learning, methods, tools and organizational forms of learning. They interact with each other, determine each other, and therefore form a coherent set, which consists of the above elements. This set is a didactic system. It could still be called didactically methodical, because the study of any topic, any educational material at the stage of planning the learning process and its implementation is carried out with the participation of this system (Malfaik I., 2005: 17). The relationship between the main didactic categories as structural components of the whole didactic process are shown in Figure 1.3. Analyzing the chain of categories shown in Figure 1.3. "content" - "methodology" - "system" - "technology" note the following:

"The content of academic disciplines" is based on the formation and systematization of its logical structure, which is the methodological basis for subsequent design decisions on the methodological and technological construction of the discipline. There are many serious didactic problems in structuring the content of educational material of disciplines, which are, first of all, that it is necessary to present a large amount of educational information not just in a concise form, but to teach students creative thinking and professional mobility. This, in turn, requires the creation of a flexible system of transformation and submission of scientific information to the curriculum, so as to meet the requirements for structuring the content of educational material, namely - creating a logical structure based on the formation and systematization of content.

"Methods of teaching technological equipment" characterizes the theoretical level of interpretation of the didactic system. At this level, project decisions are laid down for the implementation of a certain strategy and tactics of operating the educational material based on the methods of organizing the educational process within a certain content of the discipline.

"Discipline teaching system" determines the system level of categorical interpretation and is manifested in a set of requirements and adaptation measures to work with the content of the discipline in certain educational conditions. This level of didactic interpretation 
is mandatory in the methodological design, because the difference between pedagogical and organizational conditions, the functioning of which focuses on the methodology of teaching the discipline, must be taken into account during its development.

"Technology of teaching the discipline" presents the technological level of implementation of teaching methods and can be interpreted in terms of the practical feasibility of the process of teaching technological equipment in the industry.

\section{Conclusions and prospects for further researches of directions}

The process of training future teachers of vocational training in the food industry will have a high end result, only if modern teaching methods, tools and technologies are rapidly implemented. This requires:

- systematically analyze the development of various areas of the food industry;

- monitor the receipt and use of modern technological equipment in food production;

- to conduct an analytical review of modern devices and equipment of food production;

- to carry out research and experimental advanced developments of methods of training of future teachers of professional training in the equipment of food productions;

- to embody problem situations in the educational process.

\section{References}

Aleksyuk, A. M. (1985). Pedagoika: navchal’ny’j posibny`k [Pedagogy: a textbook] Kiev: Vy shha shkola. [in Ukrainian]

Dubasenyuk, O. A. (2001). Texnologiyi profesijno-pedagogichnoyi pidgotovky'majbutnix uchy teliv [Technologies of professional and pedagogical training of future teachers] Zhytomyr: state Pedagogical University. [in Ukrainian]

Kurdanova, X. M., Sarbasheva, Z. M. (2008). Rol' didakticheskogo aspekta v professional'noy podgotovke studentov vuza [The role of the didactic aspect in the professional training of university students] Saratov: Fundamental research. [in Russian]

Malafiyik, I. V. (2005). Dydaktyka: Navchal'nyy posibnyk [Didactics: Textbook] Kiev: Kondor. [in Ukrainian]

Chajka, V. M. (2002). Osnovy dydaktyky: Teksty lektsiy i zavdannya dlya samokontrolyu [Fundamentals of didactics: Lecture texts and tasks for self-control] Ternopil: Aston. [in Ukrainian] Yarmachenko, M. D. (1986) Pedagogika: pidruchny`k [Pedagogy: textbook] Kiev: Vy`shha shkola. [in Ukrainian] 